\title{
REVERSAL OF REFRACTORY HYPOTENSION WITH SINGLE-DOSE METHYLENE BLUE AFTER CORONARY ARTERY BYPASS SURGERY
}

\author{
P. Yiu, FRCS, ${ }^{\mathrm{a}} \mathrm{J}$. Robin, MRCP, ${ }^{\mathrm{b}}$ and C. W. Pattison, FRCS, ${ }^{\mathrm{a}}$ London, United Kingdom
}

Low systemic vascular resistance (SVR) requiring vasoconstrictor therapy is a recognized complication of cardiopulmonary bypass. We present here a case in which norepinephrine therapy had failed and alternative strategy with a guanylate cyclase inhibitor, methylene blue, was instituted, resulting in a rapid, permanent restoration of hemodynamic stability.

Clinical summary. A 72-year-old man with 3-vessel disease and moderate left ventricular function was admitted for coronary artery bypass surgery. Coronary risk factors included hypercholesterolemia, hypertension, prior smoking, and a family history of heart disease. He was on a program of amlodipine, atenolol, enalapril, simvastatin, and aspirin. Medical history included a cerebrovascular accident. His blood pressure was $150 / 90 \mathrm{~mm} \mathrm{Hg}$ and he had atrial fibrillation with a pulse rate of 60 beats/min. Baseline blood results were normal apart from a borderline serum creatinine value of $105 \mu \mathrm{mol} / \mathrm{L}$.

Coronary artery bypass grafting was performed under normothermic conditions with intermittent crossclamp fibrillation. The operation was uneventful and total bypass time was 67 minutes. He was transferred to the intensive care unit receiving intravenous glyceryl trinitrate $(2 \mathrm{~mL} / \mathrm{h})$ and cardiac dopamine $(10.9 \mu \mathrm{g} / \mathrm{kg}$ per minute). Four hours after the operation, his blood pressure progressively sagged. The central venous pressure was $10 \mathrm{~mm} \mathrm{Hg}$ and the hemoglobin level was $8.9 \mathrm{~g} / \mathrm{dL}$ after a total of $2.5 \mathrm{~L}$ of colloid and 1 unit of blood. Blood loss was negligible and oxygen tension was

From the Cardiothoracic Surgical Unit ${ }^{\mathrm{a}}$ and Departments of Intensive Care and Clinical Pharmacology, ${ }^{\mathrm{b}}$ University College and Middlesex Hospitals, London, United Kingdom.

Received for publication Jan 14, 1999; accepted for publication March 8, 1999.

Address for reprints: Patrick Yiu, FRCS, Cardiothoracic Surgical Unit, 4th Floor, Middlesex Hospital, Mortimer Street, London W1N 8AA, United Kingdom.

J Thorac Cardiovasc Surg 1999;118:195-6

Copyright (C) 1999 by Mosby, Inc.

$0022-5223 / 99 \$ 8.00+0 \quad \mathbf{1 2 / 5 4 / 9 8 4 2 5}$
$13.5 \mathrm{kPa}$ on an inspired oxygen fraction of 0.4 . The electrocardiogram showed no ischemic changes. The dopamine infusion was reduced to a renal dose, and an epinephrine infusion was commenced at $5 \mu \mathrm{g} / \mathrm{min}$, but this needed to be increased to $13 \mu \mathrm{g} / \mathrm{min} 4$ hours later (Fig 1). Esophageal Doppler monitoring showed a high cardiac output of 8.4 $\mathrm{L} / \mathrm{min}$ with a low calculated SVR of 455 dynes $\cdot \mathrm{sec} / \mathrm{cm}^{5}$. As a result, norepinephrine was started and epinephrine was weaned. Over the course of 9 hours the patient's requirement for norepinephrine to maintain a systolic pressure above 90 $\mathrm{mm} \mathrm{Hg}$ escalated to $45 \mu \mathrm{g} / \mathrm{min}$. His cardiac output was 9.2 $\mathrm{L} / \mathrm{min}$ and the SVR was still low at 550 dynes $\cdot \mathrm{sec} / \mathrm{cm}^{5}$. Methylene blue $(2 \mathrm{mg} / \mathrm{kg})$ was given intravenously over 20 minutes with an immediate rise in blood pressure. Within the hour, the norepinephrine infusion was discontinued. His hemodynamic state remained stable on epinephrine alone (10 $\mu \mathrm{g} / \mathrm{min})$. No additional methylene blue was required and he was weaned off all inotropic support the following day.

He remained apyrexial with a normal white cell count. All microbial cultures were negative. Apart from routine prophylactic antibiotics, he received no other antimicrobial therapy. The postoperative amylase value was within normal limits.

His postoperative recovery was delayed by acute nonoliguric renal dysfunction with a creatinine peak of $358 \mu \mathrm{mol} / \mathrm{L}$ and a popliteal deep vein thrombosis. Both complications resolved with conservative management.

Discussion. The mechanism behind low SVR after cardiopulmonary bypass is poorly understood but is related to activation of an inflammatory response. ${ }^{1}$ Preoperative use of angiotensin-converting enzyme inhibitors is a possible predisposing factor. ${ }^{2}$ Some patients with significant low SVR require vasoconstrictor therapy, typically norepinephrine. Our patient was norepinephrine resistant and urgently needed an alternative approach. We found that methylene blue (2 $\mathrm{mg} / \mathrm{kg}$ ) was remarkably effective, and a single dose was sufficient to permanently restore hemodynamic stability. The clinical response was correlated with normalization of the SVR and cardiac output.

Published data to date have seen methylene blue (a guanylate cyclase inhibitor) being used primarily in septic shock. Endotoxemia induces substantial nitric oxide release, which 


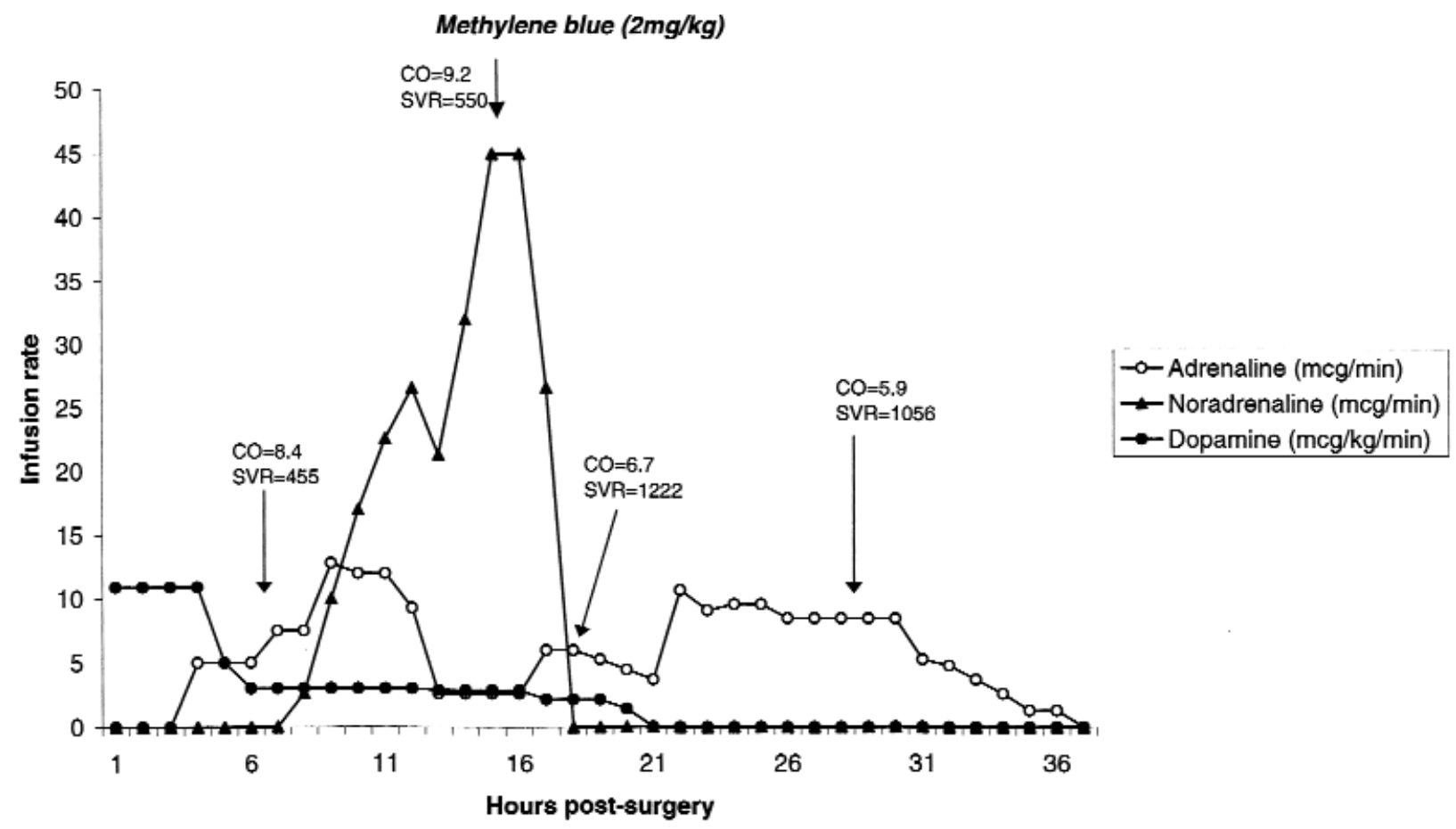

Fig 1. Diagram illustrating the patient's inotropic requirements after coronary artery bypass surgery. Hemodynamic indices are also shown. $C O$, Cardiac output; $S V R$, systemic vascular resistance.

stimulates guanylate cyclase in vascular smooth muscle cells, resulting in loss of vasomotor tone. ${ }^{3,4}$ Interestingly, there was no evidence of sepsis in this patient. The sustained effect of the single-dose treatment would also support a pro-inflammatory insult. Thus the favorable response to methylene blue suggests that abnormal activation of the nitric oxide pathway may play a significant role in the low SVR syndrome after cardiopulmonary bypass. Previous attempts to identify an increase in nitric oxide release after bypass have failed to find a rise in serum or urine nitrate/nitrite levels (stable breakdown products of nitric oxide) compared with prebypass levels. ${ }^{5}$ However, determination of nitric oxide activity using nitrate/nitrite assay alone can be unreliable. It is also possible to hypothesize that proinflammatory mediators arising from cardiopulmonary bypass do not act by stimulating nitric oxide release but through activation of the final common pathway of nitric oxide (ie, guanylate cyclase), or else they sensitize vascular smooth muscle cells to the action of nitric oxide.

Conclusions. A single dose of methylene blue successfully reversed refractory hypotension after cardiopulmonary bypass in nonsepsis. Activation of guanylate cyclase in vascular smooth muscle may play a key role in the postpump low SVR syndrome and warrants further studies.

\section{REFERENCES}

1. Hill GE. Cardiopulmonary bypass-induced inflammation: Is it important? J Cardiothorac Vasc Anesth 1998;12(2 Suppl 1):21-5.

2. Tuman KJ, McCarthy KJ, O'Connor CJ, Holm WE, Ivankovich $\mathrm{AD}$. Angiotensin-converting enzyme inhibitors increase vasoconstrictor requirements after cardiopulmonary bypass. Anesth Analg 1995;80:473-9.

3. Preiser JC, Lejeune P, Roman A, Carlier E, De Backer D, Leeman $\mathrm{M}$, et al. Methylene blue administration in septic shock: a clinical trial (see comments). Crit Care Med 1995;23:259-64.

4. Galili Y, Kluger Y, Miamski Z, Laina A, Wollman Y, Marmur S. Methylene blue: a promising treatment modality in sepsis induced by bowel perforation. Eur Surg Res 1997;29:390-5.

5. Myles PS, Leong CK, Currey J. Endogenous nitric oxide and low systemic vascular resistance after cardiopulmonary bypass. J Cardiothorac Vasc Anesth 1997;11:571-4. 